\title{
Serum and tonsil tissue melatonin levels of patients with chronic tonsillitis
}

\section{Kronik tonsilitli hastalarm serum ve tonsil doku melatonin düzeyleri}

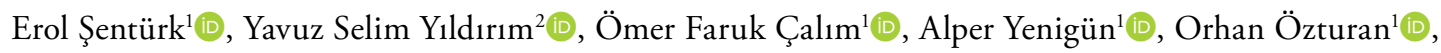

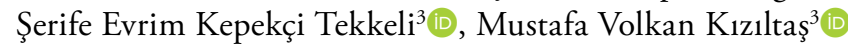 \\ ${ }^{1}$ Department of Otolaryngology, Bezmialem Vakuf University, İstanbul, Turkey \\ ${ }^{2}$ Department of Otolaryngology, Doğuş University Hospital, İstanbul, Turkey \\ ${ }^{3}$ Department of Analytical Chemistry, Bezmialem Vakif University Faculty of Pharmacy
}

\section{ABSTRACT}

Objectives: This study aims to compare the serum, tonsil surface epithelial tissue and parenchyma levels of melatonin in children who underwent tonsillectomy due to recurrent tonsillitis.

Patients and Methods: The study included 33 pediatric patients (17 males, 16 females; mean age 7.3 years; range, 3 to 10 years) scheduled for tonsillectomy surgery. Five milliliter venous blood samples and $25 \mathrm{~g}$ of two different types of tonsil tissues, parenchyma and capsule were collected from the patients and stored. High performance liquid chromatography was used for the determination of melatonin in plasma and tissue samples.

Results: The tonsil surface tissue levels of melatonin were lower than the simultaneous plasma levels of melatonin $(\mathrm{p}<0.0135)$. The plasma levels of melatonin were higher than the simultaneous tonsil parenchyma tissue levels of melatonin $(\mathrm{p}<0.016)$. The tonsil surface tissue levels of melatonin were lower than the simultaneous tonsil parenchyma tissue levels of melatonin $(\mathrm{p}<0.002)$.

Conclusion: The plasma concentrations of melatonin and tonsil surface epithelial tissue and parenchyma concentrations of melatonin in children with chronic tonsillitis were low. According to this finding, we may recommend serum levels of melatonin to be checked in patients indicated for tonsillectomy. Keywords: Immunomodulatory, melatonin level, recurrent tonsillitis, tonsillectomy.

\section{$\ddot{O} Z$}

Amaç: Bu çalışmada tekrar eden tonsilit nedeniyle tonsillektomi geçiren çocuklarda serum, tonsil yüzey epitel doku ve parankim melatonin düzeyleri karşılaştırıldı.

Hastalar ve Yöntemler: Çalışmaya tonsillektomi cerrahisi planlanan 33 pediatrik hasta (17 erkek, $16 \mathrm{kız}$; ort. yaş 7.3 yıl; dağılım, 3-10 yıl) dahil edildi. Hastalardan $5 \mathrm{~mL}$ venöz kan örneği ve $25 \mathrm{~g}$ iki farklı tonsil doku, parankim ve kapsül toplandı ve saklandı. Plazma ve doku örneklerindeki melatoninin saptanmasında yüksek performanslı sıvı kromatografisi kullanıldı.

Bulgular: Tonsil yüzey doku melatonin düzeyleri eş zamanlı plazma melatonin düzeylerinden daha düşük idi $(\mathrm{p}<0.0135)$. Plazma melatonin düzeyleri eş zamanlı tonsil parankim doku melatonin düzeylerinden daha yüksek idi $(\mathrm{p}<0.016)$. Tonsil yüzey doku melatonin düzeyleri eş zamanlı tonsil parankim doku melatonin düzeylerinden daha düşük idi $(\mathrm{p}<0.002)$.

Sonuç: Kronik tonsilitli çocuklarda plazma melatonin konsantrasyonları ve tonsil yüzey epitel doku ve parankim melatonin konsantrasyonları düşük idi. Bu bulguya göre, tonsillektomi için endike hastalarda serum melatonin düzeylerinin kontrol edilmesini önerebiliriz.

Anahtar sözcükler: İmmünmodülatör, melatonin düzeyi, tekrar eden tonsilit, tonsillektomi.

Received: August 08, 2018 Accepted: February 09, 2019 Published online: March 28, 2019

Correspondence: Erol Şentürk, MD. Bezmiâlem Vakıf Üniversitesi Kulak Burun Boğaz Anabilim Dalı, 34093 Fatih, İstanbul, Turkey. e-mail: erolsent@gmail.com

\section{Citation:}

Şentürk E, Yıldırım YS, Çalım ÖF, Yenigün A, Özturan O, Kepekçi Tekkeli ŞE, et al. Serum and tonsil tissue melatonin levels of patients with chronic tonsillitis. KBB Uygulamaları 2019;7(2):80-84. 
Tonsillectomy is the most common surgical operation performed in the practice of otorhinolaryngology. According to the Paradise Criteria, children identified to have at least seven tonsillitis attacks in one year, at least five in two years and at least three in three years are indicated for tonsillectomy. ${ }^{[1]}$ It was demonstrated that pediatric tonsil tissues have higher concentration of lymphocytes as compared to adults and that the sub-types of lymphocytes $B$ and $T$ are reduced in tonsil tissues of those who frequently have tonsillitis attacks. ${ }^{[2,3]}$

Melatonin ( $\mathrm{N}$-acetyl-5-methoxytryptamine) is a neuromodulator hormone that is rhythmically secreted from the pineal gland into the plasma in dark. ${ }^{[4]}$ Melatonin has shown to be protective against functional disorders in various organs in cases of viral and bacterial infections. ${ }^{[5]}$ Previous studies demonstrated the presence of melatonin receptors in human lymphocytes. ${ }^{[6]}$ Tonsils are lymphoid organs in which B lymphocytes are particularly dominant. It was seen that melatonin and phytohemagglutinin culture caused an increase in the number and percentage of B lymphocyte sub-types and that the same increase was not observed in the T lymphocytes or natural killer cells. ${ }^{[7]}$

The immunomodulatory role of melatonin is related in part to its action on specific melatonin receptors located in immunocompetent cells. Human lymphocyte-synthesized melatonin may play a crucial role in modulating the interleukin (IL)-2/IL-2 receptor system, as indicated by studies showing that both IL-2 and IL-2 receptor levels decreased when melatonin biosynthesis was blocked by the tryptophan hydroxylase inhibitor parachlorophenylalanine.

The action of melatonin on monocyte production can be partly due to its direct action on melatonin receptors or it may be due to an increase in monocyte sensitivity to stimulants like IL-3, IL-4, IL-6 or granulocyte macrophage colony-stimulating factor. In this study, we aimed to compare the serum, tonsil surface epithelial

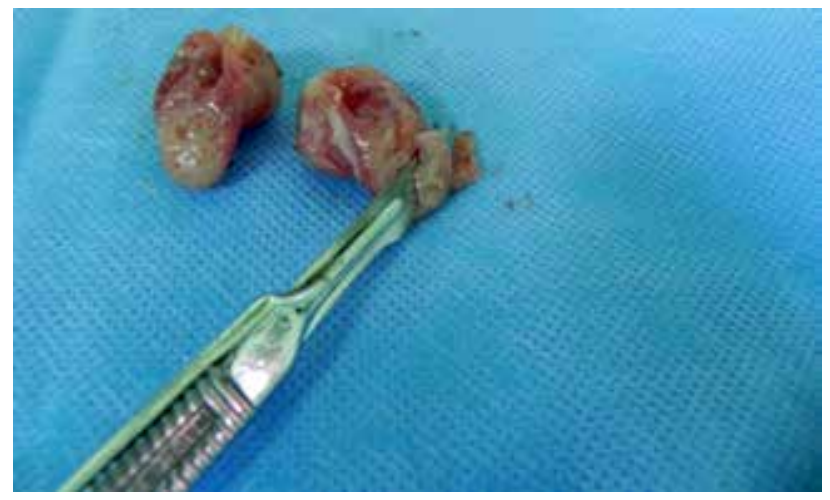

Figure 1. Tonsil surface tissue. tissue and parenchyma levels of melatonin in children who underwent tonsillectomy due to recurrent tonsillitis.

\section{PATIENTS AND METHODS}

This study was conducted at Bezmialem Vakif University Hospital between January 2017 and November 2017 and included 33 pediatric patients $(17$ males, 16 females; mean age 7.3 years; range, 3 to 10 years) who presented due to frequent tonsillitis attacks and were scheduled for tonsillectomy surgery. Each patient received an endoscopic ear, nose and throat examination. Those with any ear problems, allergic rhinitis, chronic inflammatory disease, those who had presented before to the psychiatric outpatient clinic for any reason, or had obesity, cranio-facial abnormality, or mental problems such as mental retardation were excluded. The study protocol was approved by the Bezmialem Vakif University Hospital Ethics Committee (050.01.04/556). A written informed consent was obtained from parents of each patient. The study was conducted in accordance with the principles of the Declaration of Helsinki.

Five milliliter venous blood samples were collected from peripheral veins of patients into tubes containing disodium ethylenediaminetetraacetic acid (EDTA) and centrifuged at $4500 \times \mathrm{g}$ for 10 minutes. The resultant plasma samples were stored at $-20^{\circ} \mathrm{C}$. Approximately $25 \mathrm{~g}$ of two different types of tonsil tissues, parenchyma and capsule were collected from patients and stored at $-80^{\circ} \mathrm{C}$ until the analysis. Tonsil surface epithelium was dissected sharply with scalpel number 11 (Figures 1, 2).

Melatonin was purchased from Sigma-Aldrich (Sigma-Aldrich, St. Louis, MO, USA). Solvents were high performance liquid chromatography (HPLC)grade acetonitrile, chloroform, and acetic acid. All other solvents and chemicals were of analytical grade. Stock standard solutions of melatonin were prepared in water and stored at $4^{\circ} \mathrm{C}$. The water was purified using

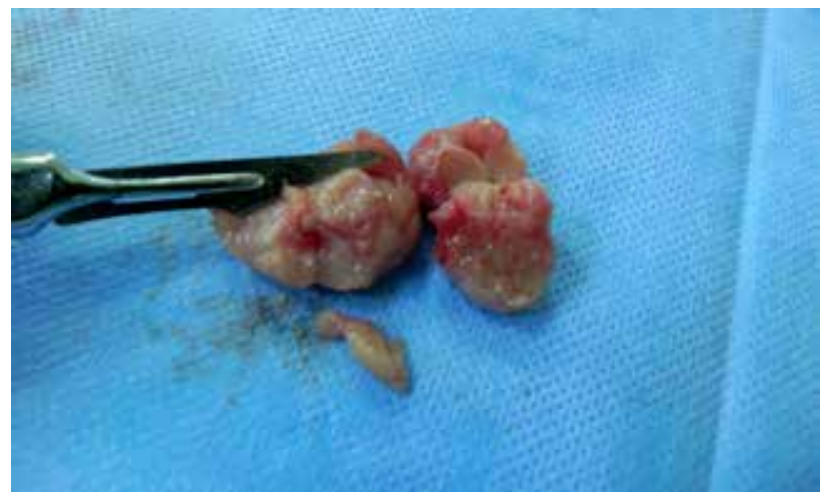

Figure 2. Tonsil parenchyma tissue. 


\begin{tabular}{|lccccccc|}
\hline \multicolumn{7}{|c|}{ Table 1} \\
\multicolumn{7}{|c}{ Plasma tonsil surface tissue and parenchyma levels of melatonin } \\
& $\mathrm{n}$ & Mean \pm SD & Median & Min-Max & RSD & $95 \%$ CI & Variance \\
\hline Plasma $(\mathrm{pg} / \mathrm{mL})$ & 33 & $0.8 \pm 0.8$ & 0.66 & $0.030-2.90$ & 0.93 & $0.53-1.07$ & 0.56 \\
Surface $(\mathrm{pg} / \mathrm{mL})$ & 33 & $0.4 \pm 0.3$ & 0.32 & $0.010-1.12$ & 0.83 & $0.24-0.51$ & 0.10 \\
Core $(\mathrm{pg} / \mathrm{mL})$ & 33 & $0.6 \pm 0.6$ & 0.54 & $0.020-3.10$ & 1.15 & $0.27-0.83$ & 0.41 \\
\hline SD: Standard deviation; Min: Minimum; Max: Maximum; RSD: Relative standard deviation; CI: Confidence interval. & \\
\hline
\end{tabular}

the Human Corporation ultra-water purification system (Human Corporation, Tokyo, Japan).

To extract melatonin from the plasma samples, $200 \mu \mathrm{L}$ plasma was acidified with $200 \mu \mathrm{L} 0.1 \mathrm{M}$ acetic acid ( $\mathrm{pH}$ 4.6). Then, the solution was extracted into $2 \mathrm{~mL}$ chloroform. The contents were mixed using a vortex mixer at a moderate speed for five minutes and centrifuged at $4500 \times \mathrm{g}$ for three minutes. The aqueous layer was discarded. The organic phase was alkalinized with $500 \mu \mathrm{L} 0.1 \mathrm{~N} \mathrm{NaOH}$ by mixing with a vortex mixer. The organic phase was taken after centrifugation at $4500 \times \mathrm{g}$ for two minutes and evaporated to dryness under a stream of nitrogen at $40^{\circ} \mathrm{C}$. $100 \mu \mathrm{L}$ mobile phase was added onto the residue and the solution was filtered, $20 \mu \mathrm{L}$ of the filtrate was injected to the HPLC system. To extract melatonin from each type of tissues, $20 \mathrm{mg}$ tissue sample was homogenized; $2 \mathrm{~mL} 0.1 \mathrm{M}$ acetic acid ( $\mathrm{pH} 4.6$ ) was added onto the samples. The contents were mixed with a vortex mixer at a moderate speed for five minutes and centrifuged at $4500 \times \mathrm{g}$ for three minutes. The supernatant was taken and extracted into $2 \mathrm{~mL}$ chloroform. The extract was processed with the same procedures as plasma extracts were processed after extraction step.

A high performance liquid chromatography method was developed and validated for the determination of melatonin in plasma and tissue samples. The HPLC analyses were performed on a Shimadzu (Shimadzu Corporation, Tokyo, Japan) LC 20 liquid chromatograph, which consisted of a LC-20AT pump, a SIL AT-HT autosampler part, a SPD-20A HT fluorimetric detector, which was set at $285 \mathrm{~nm}$ for excitation and $360 \mathrm{~nm}$ for emission. A CTO-10 AC column oven (SpectraLab Scientific Inc., Markham, ON, Canada) was used. Chromatographic separation was achieved isocratically at $30^{\circ} \mathrm{C}$ on a GL Sciences (GL Sciences, Tokyo, Japan) C18 octadecylsilyl groups (ODS) column with the dimensions of $4.6 \mathrm{~mm}$ I.D., $100 \mathrm{~mm}$ length and $3 \mu \mathrm{m}$ particle size. The mobile phase consisted of an $85 \mathrm{mM}$ acetic acetate buffer and $0.1 \mathrm{M}$ EDTA-Na2 mixture and acetonitrile (86:14) with a flow rate of $1.0 \mathrm{~mL} /$ minute. The quantification of melatonin peaks was carried out using a calibration curve prepared using standard melatonin solutions.

\section{Statistical analysis}

The statistical analysis was carried out using the SPSS for Windows version 13.0 software (SPSS Inc., Chicago, IL, USA). All quantitative variables were estimated using measures of central location (i.e. mean and median) and measures of dispersion (i.e. standard deviation). Data normality was checked using the Kolmogorov-Smirnov tests of normality. For comparing the inter-group data, one-way analysis of variance and t-test were used. The statistical significance level was set at $\mathrm{p}<0.05$.

\section{RESULTS}

The plasma concentration of melatonin was $0.80 \mathrm{pq} / \mathrm{mL}$ on average (range, 0.53-1.07). The tonsil surface tissue concentration of melatonin was 0.37 on average (range, 0.24-0.51). The tonsil core tissue concentration of melatonin was 0.55 on average (range, 0.27-0.83) (Table 1).

The tonsil surface tissue levels of melatonin were lower than the simultaneous plasma levels of melatonin at a statistically significant rate $(p<0.0135)$. The plasma levels of melatonin were higher than the simultaneous tonsil parenchyma tissue levels of melatonin at a statistically significant rate $(p<0.016)$. The tonsil surface tissue levels of melatonin were lower than the simultaneous tonsil parenchyma tissue levels of melatonin at a statistically significant rate $(\mathrm{p}<0.002)$.

\section{DISCUSSION}

Melatonin is a potent hormone that is generated in the pineal gland from tryptophan, an essential amino acid. ${ }^{[8]}$ The first finding on the immunological role of melatonin is credited to Maestroni et al. ${ }^{[9]}$ It was seen that immune functions were suppressed in circumstances where melatonin formation was inhibited such as the exposure of mice to continuous light or nocturnal administration of $\beta$-adrenergic receptor blockers. The 
results obtained from consequent studies supported the view that melatonin enhanced the humoral and cellular immune response. ${ }^{[9]}$

Wichmann et al. ${ }^{[10]}$ reported that the suppression of immune functions in mice as a result of soft tissue trauma and hemorrhagic shock was reversed by melatonin; furthermore, the chronic melatonin treatment enhanced the leukocyte natural killer activity in human beings. It was shown that melatonin was protective against functional disorders in various organs in cases of viral and bacterial infections. ${ }^{[5]}$ So far, melatonin receptors have been shown in human lymphocytes, ${ }^{[6]}$ human neutrophils, ${ }^{[11]}$ spleen $^{[12]}$ and thymus. ${ }^{[13]}$

Melatonin is bound to its receptors in type $1 \mathrm{~T}$ helper (Th1) and Th2 lymphocytes ${ }^{[13-15]}$ and increases the cytokine production. ${ }^{[16]}$ The induction of IL-2 and IL-12 production by melatonin enhances the activity of natural killer cells. Furthermore, melatonin also generally stimulates hematopoiesis, thereby increasing the number of granulocyte and macrophage progenitor cells. ${ }^{[17]}$

Macrophages produce nitric oxide (NO) for microbicidal effects. When produced at a high amount, NO may cause degenerative damage in the human body. Melatonin also suppresses the inducible NO production, thereby assuming a protective role against this harmful effect. $^{[18]}$

Furthermore, the antiapoptotic effect of melatonin on thymocytes was proven as it was shown that it increased the total thymocyte count in mice. ${ }^{[19]}$ Melatonin inhibits glucocorticoid and hydroxylradicalinduced thymic apoptosis. ${ }^{[20]}$

An immunotherapy conducted with IL-2 and melatonin provided benefits against gastrointestinal system tumors. ${ }^{[21]}$ N1-acetyl-N2-formyl-5-methoxykynuramine, which is an oxidation product of melatonin, has an activating effect on neutrophils. However, both molecules inhibit the release of IL-8 and tumor necrosis factor-alpha from neutrophils. Therefore, they are able to restrain acute and chronic inflammations. ${ }^{[22]}$

Moreover, a study conducted on mice by $\mathrm{Yu}$ et al. ${ }^{[23]}$ showed that oral melatonin treatment prolonged the life of B lymphocyte precursors, the main cells of humoral immunity, and inhibited the apoptosis, thereby increasing the mature B lymphocyte counts.

Melatonin was also used for therapeutic purposes in diseases such as Parkinson's, ${ }^{[24]}$ Alzheimer ${ }^{[25]}$ and epilepsy $^{[26]}$ because of its antioxidant and free radical scavenging properties. ${ }^{[27,28]}$
Tonsil epithelial and tissue melatonin levels were studied separately since B lymphocytes are dominant in surface epithelium while $\mathrm{T}$ lymphocytes are dominant in interfollicular epithelium. In addition, melatonin restores the percentages of tonsillar lymphocyte subsets of B cells after culture and increases when the lymphocytes are stimulated with melatonin. ${ }^{[7]}$

Taking into account these properties of melatonin, it was considered that there might be a deficiency in the serum concentrations of melatonin in children with more than seven tonsillitis attacks per year and who have chronic tonsillitis. Furthermore, this study was also conducted based on the hypothesis that the melatonin concentrations in the tonsil tissue of these patients might be low due to melatonin receptor deficiency. Since the plasma melatonin peaks at 02:00-04:00 a.m., the plasma samples were collected during surgery rather than having the patient hospitalized one night before the surgery and the simultaneous tonsil surface tissue and tonsil parenchyma tissue concentrations of melatonin were compared. Our study indicated that the tonsil surface epithelial tissue concentration of melatonin was lower than the simultaneous tonsil tissue parenchyma concentration of melatonin and plasma concentration of melatonin at a statistically significant rate, supporting our hypothesis. Thus, melatonin, which is used to treat many diseases, may also be used in children with chronic tonsillitis based on results of advanced studies.

This study has some limitations. It was not possible in ethical terms to collect tonsil tissues from children who did not have tonsillitis; therefore, no comparison could be performed with tonsil tissues of healthy children. However, to our knowledge, there are no studies in the literature on this topic and this study is the first in its field to be a guide for future studies.

In conclusion, melatonin has antioxidant, antiinflammatory, immunomodulator and antiviral effects. The plasma concentrations of melatonin and tonsil surface epithelial tissue and parenchyma concentrations of melatonin in children with chronic tonsillitis were low. According to this finding, we may recommend serum levels of melatonin to be checked in patients indicated for tonsillectomy. Further studies are required to demonstrate whether oral melatonin treatment can reduce tonsillitis attacks or not.

\section{Declaration of conflicting interests}

The authors declared no conflicts of interest with respect to the authorship and/or publication of this article.

\section{Funding}

The authors received no financial support for the research and/or authorship of this article. 


\section{REFERENCES}

1. Paradise JL, Bluestone CD, Bachman RZ, Colborn DK, Bernard BS, Taylor FH, et al. Efficacy of tonsillectomy for recurrent throat infection in severely affected children. Results of parallel randomized and nonrandomized clinical trials. N Engl J Med 1984;310:674-83.

2. Sugiyama M, Sasaki T, Nakai Y, Otani S, Kinoshita Y. Studies on the cell-mediated immune response of tonsillar lymphocytes with regard to the clinical course and patient's age. Int J Pediatr Otorhinolaryngol 1982;4:193-208.

3. Brodsky L, Moore L, Stanievich JF, Ogra PL. The immunology of tonsils in children: the effect of bacterial load on the presence of B- and T-cell subsets. Laryngoscope 1988;98:93-8.

4. Reiter RJ. Pineal melatonin: cell biology of its synthesis and of its physiological interactions. Endocr Rev 1991;12:151-80.

5. Reiter RJ, Maestroni GJ. Melatonin in relation to the antioxidative defense and immune systems: possible implications for cell and organ transplantation. J Mol Med (Berl) 1999;77:36-9.

6. Lopez-Gonzalez MA, Calvo JR, Osuna C, Guerrero JM. Interaction of melatonin with human lymphocytes: evidence for binding sites coupled to potentiation of cyclic AMP stimulated by vasoactive intestinal peptide and activation of cyclic GMP. J Pineal Res 1992;12:97-104.

7. Lopez-Gonzalez MA, Guerrero JM, Sanchez B, Delgado F. Melatonin restores and enhances the human type B tonsillar lymphocyte subset in recurrent acute tonsillitis. Neurosci Lett 1998;247:131-4.

8. Kalsbeek A, Buijs RM. Output pathways of the mammalian suprachiasmatic nucleus: coding circadian time by transmitter selection and specific targeting. Cell Tissue Res 2002;309:109-18.

9. Maestroni GJ, Conti A. The pineal neurohormone melatonin stimulates activated CD4+, Thy-1+ cells to release opioid agonist(s) with immunoenhancing and antistress properties. J Neuroimmunol 1990;28:167-76.

10. Wichmann MW, Zellweger R, DeMaso, Ayala A, Chaudry IH. Melatonin administration attenuates depressed immune functions trauma-hemorrhage. J Surg Res 1996;63:256-62.

11. Lopez-Gonzalez MA, Calvo JR, Segura JJ, Guerrero JM. Characterization of melatonin binding sites in human peripheral blood neutrophils. Biotechnol Ther 1993;4:253-62.

12. Yu ZH, Yuan H, Lu Y, Pang SF. [125I]iodomelatonin binding sites in spleens of birds and mammals. Neurosci Lett 1991;125:175-8.

13. Lopez-Gonzalez MA, Martin-Cacao A, Calvo JR, Reiter RJ, Osuna C, Guerrero JM. Specific binding of 2-[125I] melatonin by partially purified membranes of rat thymus. $\mathrm{J}$ Neuroimmunol 1993;45:121-6.

14. Calvo JR, Rafii-el-Idrissi M, Pozo D, Guerrero JM.
Immunomodulatory role of melatonin: specific binding sites in human and rodent lymphoid cells. J Pineal Res 1995;18:119-26.

15. Gonzalez-Haba MG, Garcia-Mauriño S, Calvo JR, Goberna R, Guerrero JM. High-affinity binding of melatonin by human circulating $\mathrm{T}$ lymphocytes (CD4+). FASEB J 1995;9:1331-5.

16. García-Mauriño S, Pozo D, Carrillo-Vico A, Calvo JR, Guerrero JM. Melatonin activates Th1 lymphocytes by increasing IL-12 production. Life Sci 1999;65:2143-50.

17. Carrillo-Vico A, Reiter RJ, Lardone PJ, Herrera JL, Fernández-Montesinos R, Guerrero JM, et al. The modulatory role of melatonin on immune responsiveness. Curr Opin Investig Drugs 2006;7:423-31.

18. Zhang S, Li W, Gao Q, Wei T. Effect of melatonin on the generation of nitric oxide in murine macrophages. Eur J Pharmacol 2004;501:25-30.

19. Tian YM, Zhang GY, Dai YR. Melatonin rejuvenates degenerated thymus and redresses peripheral immune functions in aged mice. Immunol Lett 2003;88:101-4.

20. Tian YM, Li PP, Jiang XF, Zhang GY, Dai YR. Rejuvenation of degenerative thymus by oral melatonin administration and the antagonistic action of melatonin against hydroxyl radical-induced apoptosis of cultured thymocytes in mice. J Pineal Res 2001;31:214-21.

21. Lissoni P, Brivio F, Ardizzoia A, Tancini G, Barni S. Subcutaneous therapy with low-dose interleukin-2 plus the neurohormone melatonin in metastatic gastric cancer patients with low performance status. Tumori 1993;79:401-4.

22. Silva SO, Rodrigues MR, Carvalho SR, Catalani LH, Campa A, Ximenes VF. Oxidation of melatonin and its catabolites, N1-acetyl-N2 -formyl-5-methoxykynuramine and N1-acetyl-5-methoxykynuramine, by activated leukocytes. J Pineal Res 2004;37:171-5.

23. Yu Q Miller SC, Osmond DG. Melatonin inhibits apoptosis during early $\mathrm{B}$-cell development in mouse bone marrow. J Pineal Res 2000;29:86-93.

24. Mayo JC, Sainz RM, Tan DX, Antolín I, Rodríguez C, Reiter RJ. Melatonin and Parkinson's disease. Endocrine 2005;27:169-78.

25. Pappolla M, Reiter RJ, Bryant-Thomas TK, Poeggeler B. Oxidative mediated neurodegeneration in Alzheimer's diseases: melatonin and related oxidant as neuroprotective agents. Current Medicinal Chemistry 2003;3:33-46.

26. Srinivasan V, Pandi-Perumal SR, Cardinali DP, Poeggeler B, Hardeland R. Melatonin in Alzheimer's disease and other neurodegenerative disorders. Behav Brain Funct 2006;2:15.

27. Mollaoğlu H, Özgüner MF. Yaşlanma sürecinde melatoninin rolü. Süleyman Demirel Üniversitesi Tip Fakültesi Dergisi 2005;12:52-6.

28. Palaoğlu OS, Beşkonaklı E. Pineal bez ve yaşlanma. Turkish. Journal of Geriatrics 1998;1:13-8. 